\begin{tabular}{ll}
\hline \hline MINING AND METALLURGY INSTITUTE BOR & ISSN: 2334-8836 \\
& UDK: 622 \\
\hline \hline
\end{tabular}

UDK: $622.36 / .765(045)=20$

DOI:10.5937/MMEB1402131R

Dragan S. Radulović, Slavica R. Mihajlović, Živko T. Sekulić, Dušica R. Vučinić ${ }^{* *}$

\title{
DEFINITION THE TECHNOLOGY METHOD OF APATITE FLOTATION CONCENTRATION FROM THE PHOSPHATE DEPOSIT "LISINA““***
}

\begin{abstract}
This paper presents the importance of phosphate in the world, and the problems that arise in the process of preparing the low-grade phosphate ore for obtaining the phosphate concentrate using the flotation concentration. The apatite concentrates are obtained using the selective flotation from the silicate and oxide minerals while defining the process of selective flotation of apatite from carbonate deposits is the major problem worldwide.

The experimental part of this paper presents the results of laboratory flotation tests of phosphate ore from the surface part of the location "Panjevica" of the deposit "Liina". The results have enabled definition of the flotation process in continuous conditions of work.

Keywords: apatite, calcite, selective flotation concentration, defining the technological method
\end{abstract}

\section{INTRODUCTION}

Increase the use of phosphate as mineral, and also products derived from phosphate in the economies of all countries of the world, classifies this mineral in strategic raw materials. Phosphates are mostly used in the chemical industry for production of fertilizers around $85 \%$, then $5 \%$ is used as feed additive, and the other $10 \%$ of consumption of phosphorus in the chemical industry for other purposes [1]. The artificial phosphate (mineral) fertilizers are produced in chemical industry based on the ore or phosphate concentrate, the use of which is on the basis for achieving the yield and production of sufficient quantities of food to provide nutrition rapidly growing world population. The importance of phosphorus for living world is reflected in the fact that participates in the structure of nucleic acids, phospholipids, in the plants used to participate in transformation of sugars, proteins and other compounds $[1,2]$.

By regional geological explorations, the phosphorites in metamorphic Serbian-Macedonian mass were discovered in 1959 in the territory of Bosilegrad (southeastern of Serbia). In the period from 1959 to 1966 , detailed geological explorations of phosphorite

\footnotetext{
* Institute for Technology of Nuclear and Other Mineral Raw Materials, Franchet d'Esperey 86, 11000 Belgrade, Serbia, e-mail address:d.radulovic@itnms.ac.rs

** University of Belgrade, Faculty of Mining And Geology, Djušina 7, 11000 Belgrade, Serbia

*** This paper is the result of research on the project TR 34013 "Development of Technological Processes for Obtaining the Ecological Materials Based on Non-metallic Minerals" and the Project TR 31003 "Development of Technologies and Products Based on Mineral Raw Materials and Waste Biomass for Protection ff Natural Resources for Safe Food Production", funded by the Ministry of Education, Science and Technological Development of the Republic of Serbia for the period 2011-2014.
} 
deposit were carried out in order to establish the ore reserves, and technological studies were carried out in parallel with this work [1-3]. The last evaluation of reserves is at 100 million tones with average $\mathrm{P}_{2} \mathrm{O}_{5}$ content of $9.26 \%$. As the U.S. have given for the highest production of phosphates and fertilizers (25-40\% of world production) to those imposed quality standards and that eventually became generally accepted. For the production of fertilizer in the United States, are using different qualities of concentrate, whereby the quality of the determined content of tricalcium phosphate $\mathrm{Ca}_{3}\left(\mathrm{PO}_{4}\right)_{2}$ (TCP), or BPL (Bone Phosphate of Lime). In the U.S. there are three classes of quality concentrate of $74-70 \%$ TCP, TCP from 70 $66 \%$, and less than $66 \%$ of TCP. In addition, the quality of concentrate is defined over $\mathrm{P}_{2} \mathrm{O}_{5}$ content of which is considered that it should be more than $30 \%$ (corresponding to the content of about $66 \%$ TCP). Production of fertilizer quality ore and concentrate, in addition to the content of $\mathrm{P}_{2} \mathrm{O}_{5}$, is defined by the content of other components, as well as their relationship: $\mathrm{R}_{2} \mathrm{O}_{3} \max 2,5-4,0 \%, \mathrm{Cl}_{2}$ $\max 0.13 \%$; $\mathrm{MgO} \max 0.25 \%$; $\mathrm{CaO}: \mathrm{P}_{2} \mathrm{O}_{5}$ $\max 1.8 ; \mathrm{P}_{2} \mathrm{O}_{5}: \mathrm{F} \min 8: 1$ [4].

Methods of preparation which provide phosphate rock market quality, are differ significantly in the phases of process, depending on the $\mathrm{P}_{2} \mathrm{O}_{5}$ content in the ore, ore type, content of gangue, etc. Simple methods of preparation, such as washing, slurry and classification are applied for high-grade ore. However, due to the long-term exploitation of phosphate, which is more than a hundred and fifty years, the reserve of the high-grade deposits are largely reduced $[2,4,5]$. A significant share is exploitation of a low-grade phosphate ore, which as such cannot be used without the use of sophisticated methods of preparation. In the process of preparing the low-grade ore is necessary to increase the content of $\mathrm{P}_{2} \mathrm{O}_{5}$ and achieve the most favorable ratio $\mathrm{CaO}: \mathrm{P}_{2} \mathrm{O}_{5}$, so in the flotation concentration is usually applied for this ore, and other forms of concentration [2, 4]. Today, more than two-thirds of the world phos phates concentrate market quality obtained by the method of pre flotation in which the oxide and silicate minerals are present as minerals of tailings. Preparation of phosphate ore of sedimentary origin from the high content of carbonate is a worldwide problem and the appropriate technology at the industrial scale does not exist [6]. Since most of the world reserves of phosphate (about $80 \%$ or more) are in the form of carbonate sedimentary ore, the goal of a large number of studies in the laboratory and pilot-plant conditions, is to determine the separation of carbonate phosphate flotation process. Poorly soluble salt type minerals, such as apatite $\left(\mathrm{Ca}_{5}\left(\mathrm{PO}_{4}\right)_{3}\right)(\mathrm{F}, \mathrm{OH})$, fluorite $\left(\mathrm{CaF}_{2}\right)$, calcite $\left(\mathrm{CaCO}_{3}\right)$, scheelite $\left(\mathrm{CaWO}_{4}\right)$, magnesite $\left(\mathrm{MgCO}_{3}\right)$, barite $\left(\mathrm{BaSO}_{4}\right)$, are natural hydrophilic $[2,7,8]$. These minerals can be successfully separated from the oxide and silicate minerals by flotation process. However, based on the results from literature, it can be said that it is difficult to determine the conditions of mutual separation of salt-type minerals (e.g. apatite from calcite) of flotation process. As the reasons are similar physicochemical properties of these minerals, a partial solubility in water, the adsorption characteristics, or a similar affinity to the flotation reagents [2,9]. Especially is a large influence of chemical composition of the pulp and the ionic strength of solution, since it leads to the partial dissolution of minerals and salts of the type of playing a large number of reactions in solution. Development of these reactions in solution (pulp) may be affected by preparation method of mineral raw materials prior to flotation (grinding, grading, conditioning ...). Therefore, the surface properties of minerals from the group of apatite and associated minerals in the ore, and because of that the efficiency of the process of flotation, are significantly influenced by a complex interaction of the system before and during flotation. Accordingly, the selective flotation of phosphate is much easier to reach the ore in which silicates are present, then from the carbonate ore tailings. 
The active anionic and cationic active collectors are used for minerals of salt type. The fatty acids and their salts (soaps) from the group of anionic active oxidrill collector are commonly used for this group of minerals. Successful flotation of minerals from this group with the said collectors is achieved according to the literature data, without activating [2, 4, 7, 10-14]. As deprimators of minerals from this group are used sodium silicate, or quebracho tannin (containing $70 \%$ of tannic acid), aluminum sulfate, citric acid, dextrin, starch, alkali cellulose sulphate. If it is necessary, the salts of heavy metals, calcium and magnesium ions can be used as activators

\section{EXPERIMENTAL WORK}

\section{Preparation of Sample}

The sample of ore weight $2,000 \mathrm{~kg}$ comes from the surface part of the deposit, "Lisina" - Panjevica location. The written scheme of sample preparation of the apatite ore "Lisina" for separation the sample for laboratory and subsequent semiindustrial tests of ore is shown in Figure 1.

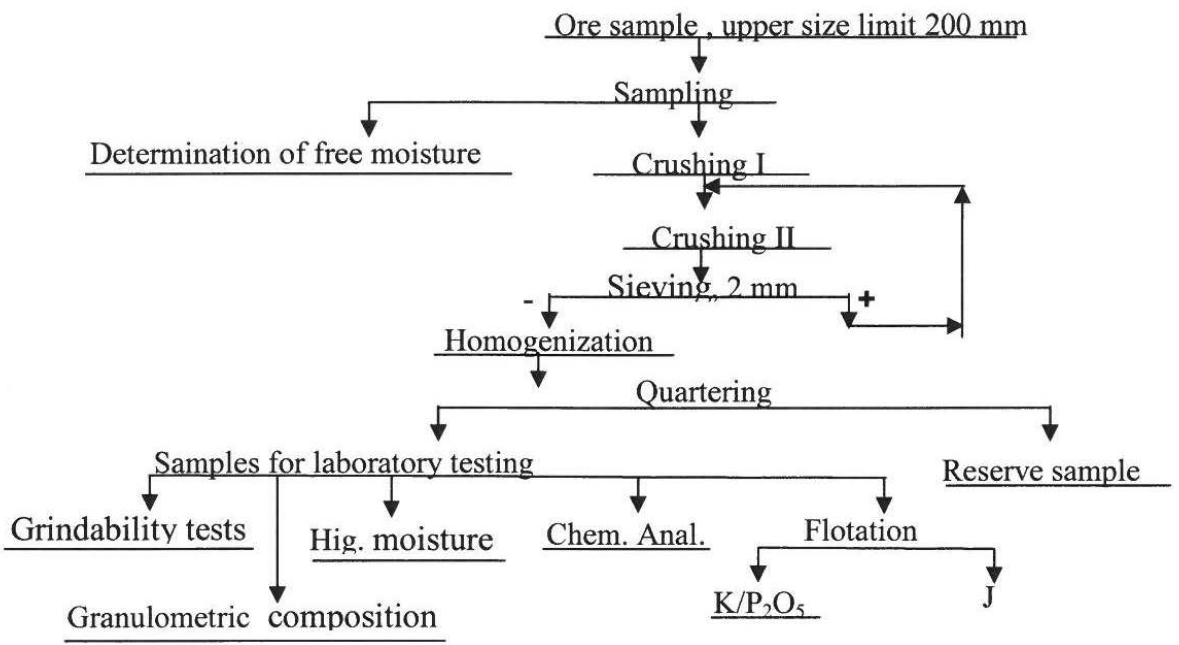

Figure 1 The written scheme of sample preparation for phosphate ore for technological testing

\section{Methods and Reagents}

Characterization of ore samples was carried out using the methods of chemical analysis and qualitative microscopic mineralogical analysis. $\mathrm{HCl}, \mathrm{NaOH}$ and $\mathrm{Na}_{2} \mathrm{CO}_{3}$ (soda ash) were used as the reagents for regulating the $\mathrm{pH}$. Na-oleate of analytical grade was applied as a collector. Tannin and $\mathrm{Na}_{2} \mathrm{SiO}_{3}$ (water glass) were used for calcite deprimating. Laboratory experiments of hydroxyapatite flotation of ore were carried out using the classical method of foam flotation in a laboratory flotation machine "Denver" D-12, with a cell volume V = 2.8 1. The floated sample these experiments, is previously prepared by wet milling process (S: $\mathrm{L}=1: 0.43$ ) up to $85 \%$ of fines $-0.074 \mathrm{~mm}$. The method and determined 


\section{RESULTS AND DISCUSSION}

\section{Basic Characteristics of the Ore Phosphate Sample - Lisina}

mode of reagents are given in a form of section of technological scheme in the part: Results and Discussion.
Chemical analysis: The results of chemical analysis of phosphate ore samples are given in Table 1.

Table 1 Chemical composition of raw phosphate ore samples "Lisina" locality "Panjevica"

\begin{tabular}{|l|c|c|c|c|c|c|c|c|c|c|c|c|}
\hline Component & $\mathrm{P}_{2} \mathrm{O}_{5}$ & $\mathrm{SiO}_{2}$ & $\mathrm{Fe}_{2} \mathrm{O}_{3}$ & $\mathrm{Al}_{2} \mathrm{O}_{3}$ & $\mathrm{TiO}_{2}$ & $\mathrm{CaO}$ & $\mathrm{MgO}$ & $\mathrm{Na}_{2} \mathrm{O}$ & $\mathrm{K}_{2} \mathrm{O}$ & $\mathrm{S}$ & G. ̌̆. & $\mathrm{U}$ \\
\hline Content, \% & 16.33 & 34.48 & 2.40 & 7.74 & 0.30 & 30.40 & 0.30 & 0.25 & 2.45 & 0.65 & 4.35 & $6.00 \mathrm{ppm}$ \\
\hline
\end{tabular}

\section{Laboratory Experiments of Flotation}

Mineralogical analysis: Qualitative microscopic mineralogical analysis showed that in a sample of ore, in addition to hydroxyapatite, are present: quartz, sericite, calcite, biotite with chlorite, fine grained epidote, tourmaline, opaque mineralsorganic matter, dolomite, limonite and hematite.
These tests have confirmed the preferred reagent regime and gave an insight into the impact of increased of solid phase in the process of conditioning and flotation from 25 to $35 \%$ and therefore the possible changes in technological scheme. The method and regime of reagents, at which the optimal results were obtained by the flotation, is present as written in technological scheme in Figure 2.

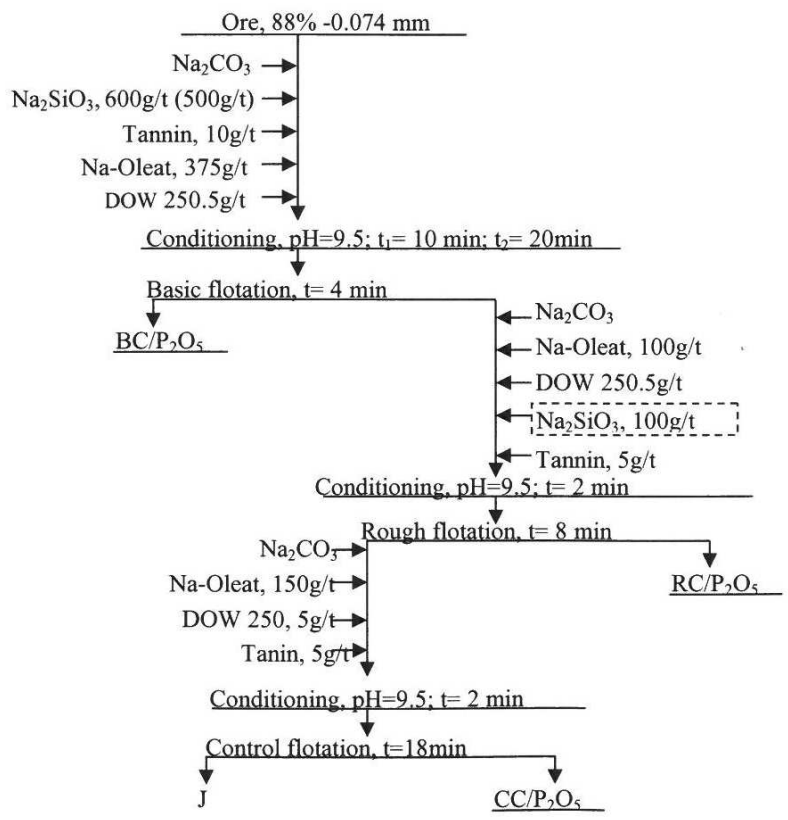

Figure 2 Schematic presentation the method and reagent regime applied in the experiments of conditioning and flotation 
Scheme for carrying out the experiments 1 and 2 is different, because that in the experiment 1 during of the conditioning prior to basic flotation, is 10 minutes, and in experiment 2 that time was 20 minutes. Also, in experiment 1 the total amount of deprimate $\mathrm{Na}_{2} \mathrm{SiO}_{3}$ than $600 \mathrm{~g} / \mathrm{t}$ is added to the conditioning before flotation, and in the experiment 2 in two portions of conditioning before flotation $500 \mathrm{~g} / \mathrm{t}$ and conditioning prior to coarse flotation was $100 \mathrm{~g} / \mathrm{t}$.

After completion of all experiments, the products were dried, weighed, and samples were given to the chemical analysis. The results of chemical analysis are shown in Table 2 in the form of balance sheet.

Table 2 Balance sheets of flotation tests

\begin{tabular}{|c|c|c|c|c|c|c|}
\hline & Products & $\mathbf{M}, \%$ & $\mathrm{P}_{2} \mathrm{O}_{5}, \%$ & $\mathrm{Fe}_{2} \mathrm{O}_{3}, \%$ & I $\mathrm{P}_{2} \mathrm{O}_{5}, \%$ & $\mathrm{I} \mathrm{Fe}_{2} \mathrm{O}_{3}, \%$ \\
\hline \multirow{7}{*}{ 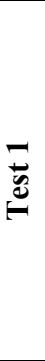 } & BC & 29.09 & 35.500 & 0.695 & 61.77 & 9.35 \\
\hline & RC & 18.15 & 27.450 & 0.971 & 29.80 & 8.15 \\
\hline & $\mathrm{BC}+\mathrm{RC}$ & 47.24 & 32.407 & 0.801 & 91.57 & 17.51 \\
\hline & $\mathrm{CC}$ & 10.51 & 11.300 & 2.283 & 7.10 & 11.10 \\
\hline & $\mathrm{BC}+\mathrm{RC}+\mathrm{CC}$ & 57.75 & 28.57 & 1.07 & 98.67 & 27.61 \\
\hline & Tailings & 42.25 & 0.525 & 3.651 & 1.33 & 71.39 \\
\hline & Input & 100.00 & 16.719 & 2.16 & 1671.9 & 216.11 \\
\hline \multirow{7}{*}{ 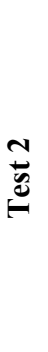 } & OK & 30.75 & 33.200 & 0.737 & 61.94 & 10.38 \\
\hline & GK & 17.59 & 28.020 & 0.956 & 29.90 & 7.70 \\
\hline & OK + GK & 48.34 & 31.315 & 0.817 & 91.84 & 18.08 \\
\hline & KK & 10.18 & 10.440 & 2.355 & 6.44 & 10.98 \\
\hline & $\mathbf{O K}+\mathbf{G K}+\mathbf{K K}$ & 58.52 & 27.68 & 1.08 & 98.28 & 29.06 \\
\hline & Tailings & 41.48 & 0.683 & 3.734 & 1.72 & 70.94 \\
\hline & Input & 100.00 & 16.485 & 2.18 & 100.00 & 100.00 \\
\hline
\end{tabular}

Based on the results shown in Table 2, it can be concluded as follows:

- Applying the flotation method, given in Figure 2, the best results are obtained both in terms of $\mathrm{P}_{2} \mathrm{O}_{5}$ and in terms of mineral content in tailings. The $\mathrm{P}_{2} \mathrm{O}_{5}$ content in the base concentrate $(\mathrm{BC})$ in the experiment 1 is $35.50 \%$, while in the experiment $2 \mathrm{BC}$ is $33.20 \%$. Total concentrate $(\mathrm{BC}+\mathrm{RC})$ in the experiment $1, \mathrm{P}_{2} \mathrm{O}_{5}$ content is $32,407 \%$ and in the experiment 2 is $31,315 \quad \mathrm{P}_{2} \mathrm{O}_{5}$ ), thereby is the use of $\mathrm{P}_{2} \mathrm{O}_{5}$ in aggregate concentrates in both experiments over $91.50 \%$.
- The content of $\mathrm{Fe}_{2} \mathrm{O}_{3}$ in both pooled concentrate was low; in the experiment $1 \mathrm{BC}+\mathrm{RC}$ is $0.801 \% \mathrm{Fe}_{2} \mathrm{O}_{3}$, and in experiment $2 \mathrm{BC}+\mathrm{RC}$ is $0.818 \% \mathrm{Fe}_{2} \mathrm{O}_{3}$.

- Regarding the control concentrate $\mathrm{CC}$ their quality is lower in terms of $\mathrm{P}_{2} \mathrm{O}_{5}$ content than feed grade (CC in the experiment 1 , is $11.30 \% \mathrm{P}_{2} \mathrm{O}_{5}$, and in the experiment 2 is $10.44 \% \mathrm{P}_{2} \mathrm{O}_{5}$ ). Utilization of $\mathrm{P}_{2} \mathrm{O}_{5}$ in the $\mathrm{BC}$ experiments 1 , is $7.10 \%$, while the content of $\mathrm{Fe}_{2} \mathrm{O}_{3}$ $2.283 \%$. Utilization of $\mathrm{P}_{2} \mathrm{O}_{5}$ in the $\mathrm{BC}$ experiments 2 is $6.44 \%$, while the content of $\mathrm{Fe}_{2} \mathrm{O}_{3} 2.355 \%$. Based on the obtained results it can be seen that the 
content of $\mathrm{Fe}_{2} \mathrm{O}_{3}$ in the control concentrates of both experiments is higher than the content of incoming raw material which is $2.16 \%$.

- $\mathrm{P}_{2} \mathrm{O}_{5}$ content in tailings is also very low, $0.525 \%$ in the experiment 1 , and 0.683 in the experiment 2 , so on the basis that the loss of $\mathrm{P}_{2} \mathrm{O}_{5}$ in the tailings very low 1.33 and $1.72 \%$.

- In comparison of these two experiments, it is shown that the achieved better quality of primary concentrates is in the experiment $1,35.50 \% \mathrm{P}_{2} \mathrm{O}_{5}$, when there is less time for the basic conditioning phase of flotation (10 min. in the experiment 1 and in the experiment 2, 20 minutes, compared to the experiment 2 when the quality of the concentrate is $33.20 \% \mathrm{P}_{2} \mathrm{O}_{5}$. From this, it can be concluded that the extended time of conditioning can lead to desorption of oleate from the surface of apatite and since the concentrate of the basic $2 \mathrm{BC}$ mass is greater than about 1.7 to $1 \%$, that the conditioning time with prolonged activation occurs and the surfaces tailings content of concentrate. Due to the use of $\mathrm{P}_{2} \mathrm{O}_{5}$ in these two concentrates is almost the same, and the amounts of $61.77 \%$ and $61.94 \%$, and the quality are different.

Based on the laboratory tests, and the obtained results (Table 2), it is defined by technological scheme of semi-industrial process and shown in Figure 3.

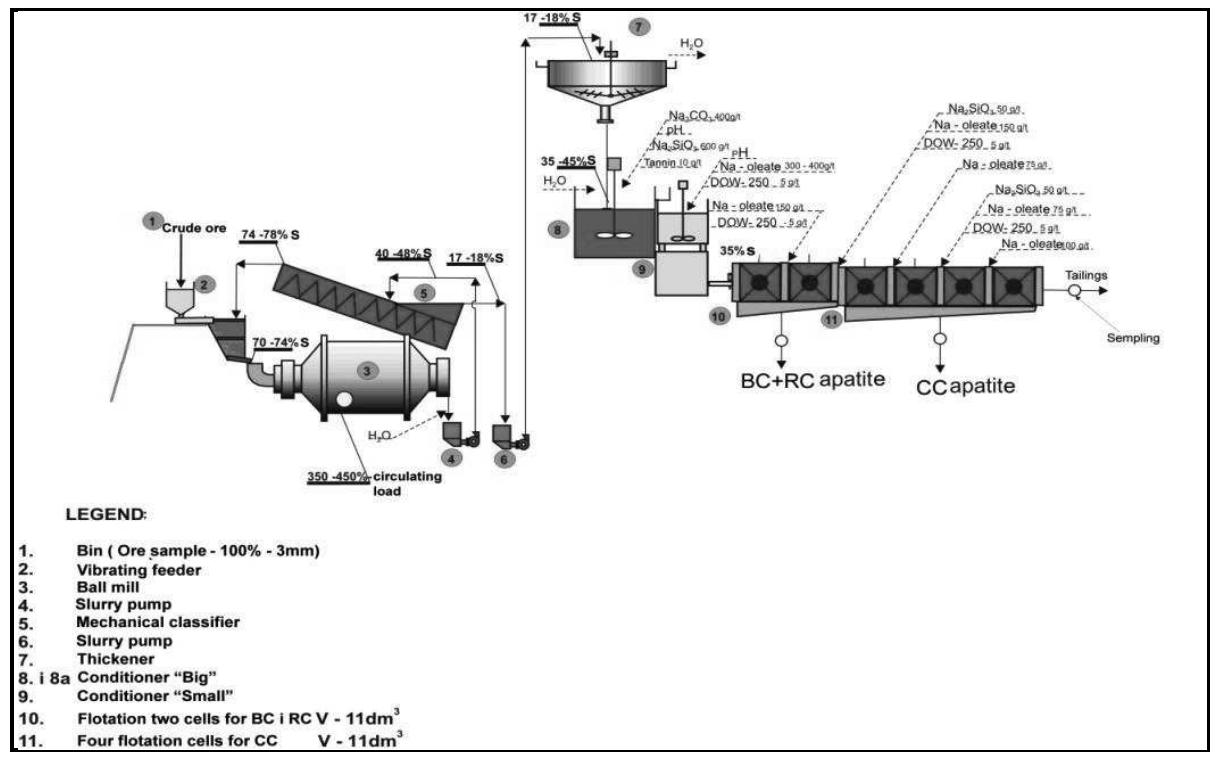

Figure 3 Defined technological flotation scheme of apatite from phosphate ore "Lisina" in semi-industrial conditions of operation

\section{CONCLUSION}

Phosphate is a strategic raw material in the international framework necessary for production of fertilizers and consequently food. Due to the long-term exploitation, the high-grade phosphate deposits were exhausted, and the deposits with lower $\mathrm{P}_{2} \mathrm{O}_{5}$ 
content of concentrates obtained by flotation. As the salt minerals (primarily calcite $\mathrm{CaCO}_{3}$ and magnesite $\mathrm{MgCO}_{3}$ ) are often found in mineral paragenesis with apatite, the method of its selective flotation from these ores is very complicated and sometimes impossible.

Based on the results presented in this paper, it can be concluded that the experiments of flotation were resulted into obtaining the concentrates of a good quality. Namely, the content of $\mathrm{P}_{2} \mathrm{O}_{5}$ in the basic experiment 1 the concentrate, is $35.50 \%$, a $\mathrm{P}_{2} \mathrm{O}_{5}$ content summaries in the experiment 2 was $33.20 \%$. The content of $\mathrm{P}_{2} \mathrm{O}_{5}$ in the block 1 is concentrate of the experiment, while $32.407 \%$ of the experiment 2 was $31.315 \%$. Utilization of $\mathrm{P}_{2} \mathrm{O}_{5}$ in the group concentrates both experiments is over then $91.5 \%$. Also, in both experiments were successfully depressed iron minerals. The content of $\mathrm{Fe}_{2} \mathrm{O}_{3}$ in each batch of concentrate is about $0.8 \%$, which is far less than $1.5 \%$ as prescribed by the chemical industry. Slightly worse results of the experiment 2 , in terms of quality concentrates, can be attributed to the prolonged period of conditioning that occurs due to desorption from the surface of collector apatite and activation of surface minerals and their tailings to concentrate. The results of the experiments were used as the basis for defining the technological process of phosphate in the semi-industrial conditions.

\section{REFERENCES}

[1] D. S. Radulović, D. Vučinić, M. Stojanović, B. Ivošević, D. Todorović, V. Jovanović, Z. Bartulović: "Improvement the Technological Method of Apatite Flotation from Phosphorous Ore "Lisina" Increasing the Content of Solid Phase from 25 to $35 \%$ in Laboratory and Semi-industrial Conditions", Technical-Technological Solution M84, 2013 (in Serbian);
[2] D. S. Radulović: "The Effect of Apatite and Calcite Ions in their Surface Properties", PhD Thesis, Faculty of Mining and Geology, University of Belgrade, 2011 (in Serbian);

[3] S. Milošević, D. Radulović, B. Ivošević, V. Antanasković, D. Vidanović, V. Djošić, Feasibility Study: "Exploitation of Phosphorous Ore from the Deposit "Lisina" near Bosilegrad and Production of Phosphorous Concentrate (K/P2O5) of Market Quality" Book 2: "Primary Processing of Phosphorous Ore "Lisina" - Production of Phosphate Concentrate (K/P2O5) of Market Quality", TechnologicalMechanical Part:, Archives of ITNMS, Belgrade, 2008 (in Serbian);

[4] J. Pavlica, D. Draškić: "Mineral Processing of Non-metallic Mineral Resources", Faculty of Geology and Mining, Belgrade 1997;

[5] A. Z. M. Abouzeid, Int. J. Miner. Process. 85 (2008) 59-84;

[6] M. Prasad, A. K. Maajmudar, T. C. Rao, SME Min. Metall. Process. 17 (1), (2000) 49-55;

[7] N. Calić: "Theoretical Basis of Mineral Processing", Belgrade, 1990;

[8] H. Sis, S. Chander, Minerals Engineering 16 (2003) 577-585;

[9] P. Somasundaran, B. Markovic, Interfacial Properties of Calcium Phosphates. In: Amjad, Z. (Ed.), Calcium Phosphates in Biological and Industrial Systems. Kluwer Academic Publishers, Dordrecht, 1998, pp. 185-201;

[10] A. M. Gaudin,: "Flotation", McGraw Hill Book Co, 1957;

[11] Đ. Lešić, S. Marković: "Mineral Processing", Belgrade, 1968 (inSerbian);

[12] H. S. Hana, and P. Somasundaran: "Flotation of Salt-Type Minerals", in M. C. Fuerstenau (Ed.), Flotation, A. M. Gaudin Memorial Vol.1, AIME, New York, NY, (1976), pp. 197-271; 
[13] R. P. King, (Ed): "Principles of Flotation", "Semisoluble Salt Flotation", M. C. Fuerstenau, Institute of Mining and Metallurgy, Johanesburg, 1982;

[14] S. Milošević: "Flotation Concentration“, Belgrade, 1994.
[15] M. Petrov, Lj. Andrić, Ž. Sekulić, V. Jovanović: Modeling the Mill Operation According to Density of Mill Batch and Specific Capacity, Mining and Metallurgy Engineering Bor, 1/2014, pp. 121-128. 


\begin{tabular}{ll}
\hline \hline INSTITUT ZA RUDARSTVO I METALURGIJU BOR & ISSN: 2334-8836 \\
& UDK: 622 \\
\hline \hline
\end{tabular}

\section{DEFINISANJE TEHNOLOŠKOG POSTUPKA FLOTACIJSKE KONCENTRACIJE APATITA IZ RUDE FOSFATA „LISINA““***}

\section{Izvod}

U radu je prikazan značaj fosfata u svetu, kao i problemi koji se javljaju u postupku pripreme siromašnijih ruda fosfata iz kojih se koncentrat fosfata dobija postupkom flotacijske koncentracije. Selektivnim flotiranjem aptita iz silikatnih $i$ oksidnih ruda se dobijaju koncentrati apatita, dok definisanje postupka selektivnog flotiranja apatita iz karbonatnih ležišta predstavlja veliki problem u svetskim razmerama.

U eksperimentalnom delu ovoga rada su prikazani rezultati laboratorijskih opita flotiranja rude fosfata iz ležišta „Lisina“- sa površinskog dela -lokalitet „Panjevica“. Dobijeni rezultati su omogućili definisanje postupka flotiranja u kontinualnim uslovima rada.

Ključne reči: apatit, kalciti, selektivna flotacijska koncentracija, definisanje tehnološkog postupka

\section{UVOD}

Porast upotrebe fosfata kao minerala, a takodje i proizvoda dobijenih od fosfata, u privredama svih zemalja sveta, svrstava ovaj mineral u strateške sirovine. Fosfati se $u$ najvećoj meri koriste u hemijskoj industriji za proizvodnju veštačkih djubriva oko $85 \%$, zatim oko $5 \%$ se koristi kao dodatak stočnoj hrani, ostalih $10 \%$ potrošnje fosfora je u hemijskoj industrij za druge namene [1]. U hemijskoj industriji se na bazi rude ili koncentrata fosfata proizvode veštačka (mineralna) fosfatna djubriva, čija upotreba predstavlja osnov za postizanje prinosa i proizvodnju dovoljnih količina hrane koje omogućavaju prehranu ubrzano rastućeg svetskog stanovništva. Značaj fosfora za živi svet ogleda se u tome što učestvuje u gradji nukleinskih kiselina, fosfolipida, u biljkama služi da učestvuje u procesima transformacije šećera, belančevina i drugih jedinjenja $[1,2]$.

Regionalnim geološkim istraživanjem, na teritoriji Bosilegrada (jugoistočna Srbija) otkriveni su, tokom 1959. godine, fosforiti u metamorfitima Srpsko-makedonske mase. U period 1959-1966. god. izvršena su detaljna geološka istraživanja fosforitskog ležišta u cilju utvrđivanja rudnih rezervi, a paralelno

\footnotetext{
* Institut za tehnologiju nuklearnih i drugih mineralnih sirovina, Franše d'Eperea 86, 11000 Beograd, Srbija,e-mail address:d.radulovic@itnms.ac.rs

** Univerzitet u Beogradu, Rudarsko geološki fakultet, Djušina 7, 11000 Beograd, Srbija

*** Ovaj rad je nastao kao rezultat istraživanja na Projektu TR 34013: „Osvajanje tehnoloških postupaka dobijanja ekoloških materijala na bazi nemetaličnih mineralnih sirovina" $i$ Projektu TR 31003: „Razvoj tehnologija i proizvoda na bazi mineralnih sirovina i otpadne biomase u cilju zaštite resursa za proizvodnju bezbedne hrane", koje finansira Ministarstvo prosvete, nauke i tehnološkog razvoja Republike Srbije za period 2011-2014.
} 
sa ovim radovima obavljena su tehnološka ispitivanja. [1-3]. Poslednja procena rezervi je na oko 100 miliona tona sa srednjim sadržajem $\mathrm{P}_{2} \mathrm{O}_{5}$ od 9,26\%. Kako su $\mathrm{SAD}$-e decenijama davale najveću proizvodnju fosfata i mineralnih djubriva (od 25-40\% svetske proizvodnje) to su one i nametnule standarde kvaliteta koji su vremenom postali opšte prihvaćeni. Za proizvodnju đubriva $u$ SAD-u, se koriste različiti kvaliteti koncentrata, pri čemu je kvalitet određen sadržajem trikalcijum-fosfata $\mathrm{Ca}_{3}\left(\mathrm{PO}_{4}\right)_{2}$, (TCP), odnosno BPL (bone phosphate of lime). U SAD$\mathrm{u}$ postoje tri klase kvaliteta koncentrata od $74-70 \%$ TCP, od 70-66\% TCP, i manje od $66 \%$ TCP. Pored toga kvaliteta koncentrata se definiše i preko sadržaja $\mathrm{P}_{2} \mathrm{O}_{5}$ za koji se smatra da treba da bude preko 30\% (odgovara sadržaju od oko $66 \%$ TCP). Za proizvodnju veštačkog đubriva kvalitet ruda i koncentrata, pored sadržaja $\mathrm{P}_{2} \mathrm{O}_{5}$, definisan je i sadržajem drugih komponenata, kao i njihovim odnosom: $\mathrm{R}_{2} \mathrm{O}_{3} \max 2,5-4,0 \% ; \mathrm{Cl}_{2}$ $\max 0,13 \% ; \mathrm{MgO} \max 0,25 \% ; \mathrm{CaO}: \mathrm{P}_{2} \mathrm{O}_{5}$ $\max 1,8 ; \mathrm{P}_{2} \mathrm{O}_{5}: \mathrm{F} \min 8: 1$ [4].

Postupci pripreme kojima se dobijaju fosfati tržišnog kvaliteta bitno se razlikuju u fazama izvođenja procesa u zavisnosti od sadržaja $\mathrm{P}_{2} \mathrm{O}_{5}$ u rudi, tipa rude, sadržaja minerala jalovine itd. Jednostavni postupci pripreme kao što su pranje, razmuljivanje i klasiranje primenjuju se kod bogatijih ruda. Međutim, zbog dugotrajne eksploatacije fosfata, koja traje više od sto pedeset godina, rezerve bogatih ležišta su u velikoj meri smanjene [2, 4, 5]. Značajan udeo u eksploataciji imaju siromašne rude fosfata, koje se kao takve ne mogu koristiti bez primene složenijih postupaka pripreme. U procesu pripreme siromašnijih ruda potrebno je povećati sadržaj $\mathrm{P}_{2} \mathrm{O}_{5}$ i postići što povoljniji odnos $\mathrm{CaO}: \mathrm{P}_{2} \mathrm{O}_{5}$, pa se kod ovih ruda najčešće primenjuje postupak flotacijske koncentracije, ali i drugi vidovi koncentracije [2, 4]. Danas se više od dve trećine svetskih koncentrata fosfata tržišnog kvaliteta dobija postupkom flotiranja rude $\mathrm{u}$ kojoj su kao minerali jalovine prisutni oksidni i silikatni minerali.

Priprema fosfatnih ruda sedimentnog porekla sa visokim sadržajem karbonata je svetski problem i adekvatna tehnologija na industrijskom nivou trenutno ne postoji [6]. Budući da je veći deo svetskih rezervi fosfata (oko $80 \%$ ili više), u obliku karbonatno sedimentnih ruda, cilj velikog broja istraživanja na laboratorijskom nivou i u pilot-postrojenjima je utvrđivanje uslova odvajanja karbonata od fosfata postupkom flotiranja. Slabo rastvorni minerali tipa soli, kao što su apatit $\left(\mathrm{Ca}_{5}\left(\mathrm{PO}_{4}\right)_{3}\right)(\mathrm{F}, \mathrm{OH})$, fluorit $\left(\mathrm{CaF}_{2}\right)$, kalcit $\left(\mathrm{CaCO}_{3}\right)$, šelit $\left(\mathrm{CaWO}_{4}\right)$, magnezit $\left(\mathrm{MgCO}_{3}\right)$, i barit $\left(\mathrm{BaSO}_{4}\right)$, su prirodno hidrofilni $[2,7,8]$. Ovi minerali se mogu uspešno odvojiti od oksidnih i silikatnih minerala postupkom flotiranja. Međutim, na osnovu rezultata iz literature može se reći da je teško utvrditi uslove međusobnog razdvajanja minerala tipa soli (npr. apatita od kalcita) postupkom flotiranja. Kao uzroci navode se slične fizičkohemijske osobine ovih minerala, delimična rastvorljivost $\mathrm{u}$ vodi, adsorpcione osobine, odnosno sličan afinitet prema flotacijskim reagensima [2, 9]. Naročito je veliki uticaj hemijskog sastava pulpe i jonske jačine rastvora, s obzirom da dolazi do delimičnog rastvaranja minerala tipa soli i odigravanja velikog broja reakcija $u$ rastvoru. $\mathrm{Na}$ odigravanje ovih reakcija $\mathrm{u}$ rastvoru (pulpi) može da utiče i način pripreme mineralne sirovine pre flotiranja (mlevenje, klasiranje, kondicioniranje...). Stoga na površinske osobine minerala iz grupe apatita i pratećih minerala u rudi, a samim tim i efikasnost postupka flotiranja, bitno utiču i veoma složene međusobne interakcije u sistemu pre i pri flotiranju. Shodno tome selektivno flotiranje fosfata se mnogo lakše postiže iz ruda u kojima su prisutni silikati, nego iz ruda sa karbonatnom jalovinom. 
Za minerale tipa soli se koriste kako anjonski aktivni tako i katjonski aktivni kolektori. Najčešće se za ovu grupu minerala koriste masne kiseline i njihove soli (sapuni) iz grupe anjonski aktivnih okshidrilnih kolektora. Uspešno flotiranje minerala iz ove grupe sa navedenim kolektorima se prema literaturnim podacima ostvaruje bez aktiviranja [2, 4, 7, 10-14]. Kao deprimatori ove grupe minerala koriste se natrijum-silikat, tanin ili kvebračo (sadrži $70 \%$ taninske kiseline), aluminijum-sulfat, limunska kiselina, dekstrin, štirak, sulfatnocelulozna lužina, itd. Ukoliko je potrebno kao aktivatori se mogu primeniti soli teških metala, joni kalcijuma i magnezijuma.

\section{EKSPERIMENTALNI RAD}

\section{Priprema uzorka}

Uzorak rovne rude mase $2.000 \mathrm{~kg}$, potiče iz površinskog dela ležišta "Lisina" - lokalitet Panjevica. Pisana šema pripreme uzorka rude apatita "Lisina" po kojoj je izdvojen uzorak za laboratorijska i za kasnija poluindustrijska ispitivanja na rudi prikazan je na slici 1 .

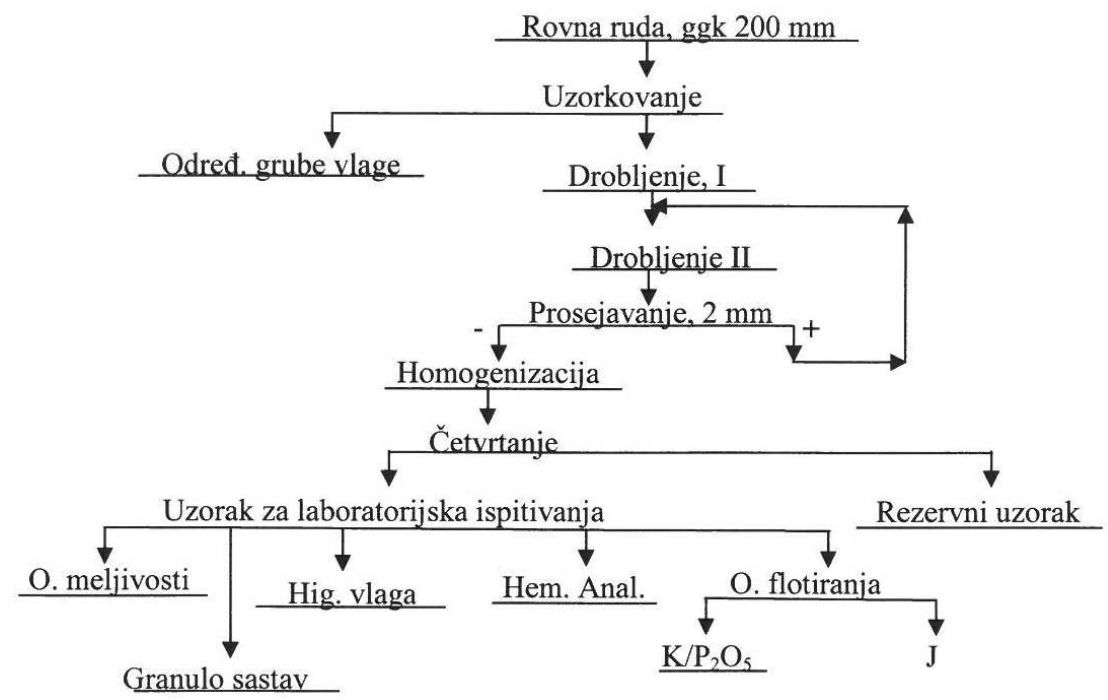

SI. 1. Pisana šema pripreme uzorka rovne rude fosfata za tehnološka ispitivanja.

\section{Metode i reagensi}

Karakterizacija uzorka rude izvršena je metodama hemijske analize i kvalitativne mikroskopske mineraloške analize. Kao reagensi za regulisanje $\mathrm{pH}$ sredine korišćeni su $\mathrm{HCl}, \mathrm{NaOH}$ i $\mathrm{Na}_{2} \mathrm{CO}_{3}$. Kao kolektor primenjivan je Na-oleat analitičke čistoće. Za deprimiranje kalcita korišćeni su tanin i $\mathrm{Na}_{2} \mathrm{SiO}_{3}$ (vodeno staklo).
Laboratorijski opiti flotiranja hidroksiapatita iz rude su izvođeni klasičnim postupkom penaste flotacije, u laboratorijskoj flotacijskoj mašini "Denver" D-12, sa ćelijom zapremine $\mathrm{V}=2,81$. Uzorak koji je flotiran u ovim opitima, prethodno je pripremljene procesom mokrog mlevenja (Č $: T=1: 0,43$ ) do finoće $85 \%-0,074 \mathrm{~mm}$. 


\section{REZULTATI I DISKUSIJA}

\section{Osnovne karakteristike uzorka rovne rude fosfata - Lisina}

Postupak i utvrdjeni režim reagenasa je dat $\mathrm{u}$ obliku tehnološke šeme u poglavlju rezultati i diskusija.

Hemijska analiza: Rezultati hemijske analize uzorka rovne rude fosfata dati su u tabeli 1.

Tabela 1. Hemijski sastav rovnog uzorka rude fosfata „Lisina “, lokalitet „,Panjevica“

\begin{tabular}{|c|c|c|c|c|c|c|c|c|c|c|c|c|}
\hline Komponenta & $\mathrm{P}_{2} \mathrm{O}_{5}$ & $\mathrm{SiO}_{2}$ & $\mathrm{Fe}_{2} \mathrm{O}_{3}$ & $\mathrm{Al}_{2} \mathrm{O}_{3}$ & $\mathrm{TiO}_{2}$ & $\mathrm{CaO}$ & $\mathrm{MgO}$ & $\mathrm{Na}_{2} \mathrm{O}$ & $\mathrm{K}_{2} \mathrm{O}$ & $\mathrm{S}$ & G. Ž. & $\mathrm{U}$ \\
\hline Sadržaj, \% & 16,33 & 34,48 & 2,40 & 7,74 & 0,30 & 30,40 & 0,30 & 0,25 & 2,45 & 0,65 & 4,35 & $6,00 \mathrm{ppm}$ \\
\hline
\end{tabular}

\section{Laboratorijski opiti flotiranja}

Mineraloška analiza: Kvalitativnom mikroskopskom mineraloškom analizom utvrđeno je da su u uzorku rude pored hidroksiapatita prisutni: kvarc, sericit, kalcit, biotit sa hloritom, sitnozrni epidot, turmalin, neprovidni minerali - organska materija, dolomit, limonit i hematit.
Ovim ispitivanjima, utvrdjen je reagentni režim i sagledavan je uticaj povećanog sadržaja čvrste faze u postupku kondicioniranja i flotiranja sa 25 na $35 \%$ i samim tim moguće izmene u tehnološkoj šemi. Postupak i režim reagenasa po kojima su dobijeni optimalni rezultati flotiranja prikazan je u obliku pisane tehnološke šeme na slici 2.

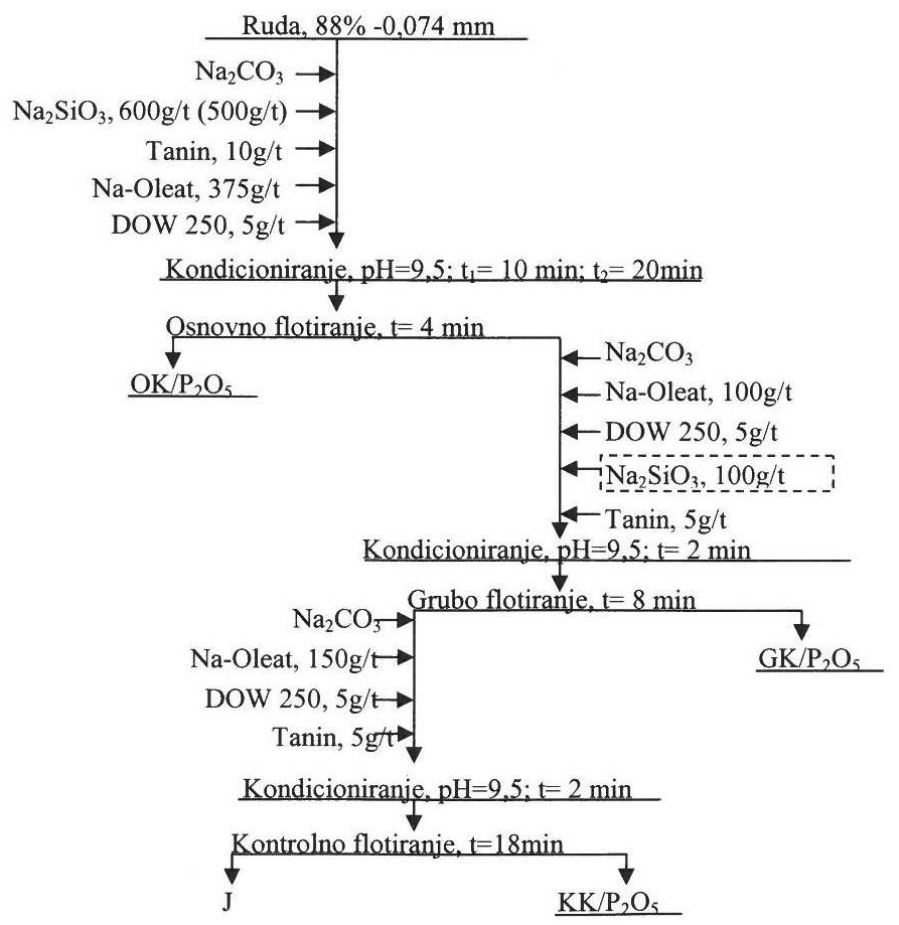

SI. 2. Šematski prikaz postupka i režima reagenasa primenjena u opitima kondicioniranja i flotiranja 
Šema za izvodjenje opita 1 i 2 se razlikuje u tome da je kod opita 1 vreme kondicioniranja pre osnovnog flotiranja 10 minuta, a u opitu 2 to vreme je iznosilo 20 minuta. Takodje, kod opita 1 ukupna količina deprimatora $\mathrm{Na}_{2} \mathrm{SiO}_{3}$ od $600 \mathrm{~g} / \mathrm{t}$ je dodata $\mathrm{u}$ kondicioniranje pre osnovnog flotiranja, a kod opita $2 \mathrm{u}$ dve porcije u kondicioniranje pre osnovnog flotiranja $500 \mathrm{~g} / \mathrm{t}$ i u kondicioniranje pre grubog flotiranja $100 \mathrm{~g} / \mathrm{t}$.

Posle završetka opita flotiranja svi proizvodi su sušeni, izmereni i uzorci su dati na hemijsku analizu. Dobijeni rezultati hemijske analize su prikazani u tabeli $2 \mathrm{u}$ obliku skupnog bilansa.

Tabela 2. Bilansi opita flotiranja

\begin{tabular}{|c|c|c|c|c|c|c|}
\hline \multicolumn{2}{|r|}{ Proizvodi } & $\mathbf{M}, \%$ & $\mathrm{P}_{2} \mathrm{O}_{5}, \%$ & $\mathrm{Fe}_{2} \mathrm{O}_{3}, \%$ & I $\mathbf{P}_{2} \mathrm{O}_{5}, \%$ & $\mathrm{I} \mathrm{Fe}_{2} \mathrm{O}_{3}, \%$ \\
\hline \multirow{7}{*}{ 号 } & OK & 29,09 & 35,500 & 0,695 & 61,77 & 9,35 \\
\hline & GK & 18,15 & 27,450 & 0,971 & 29,80 & 8,15 \\
\hline & $\mathbf{O K}+\mathbf{G K}$ & 47,24 & 32,407 & 0,801 & 91,57 & 17,51 \\
\hline & KK & 10,51 & 11,300 & 2,283 & 7,10 & 11,10 \\
\hline & $\mathbf{O K}+\mathbf{G K}+\mathbf{K K}$ & 57,75 & 28,57 & 1,07 & 98,67 & 27,61 \\
\hline & Jalovina & 42,25 & 0,525 & 3,651 & 1,33 & 71,39 \\
\hline & Ulaz & 100,00 & 16,719 & 2,16 & 1671,9 & 216,11 \\
\hline \multirow{7}{*}{$\stackrel{\sim}{0}$} & OK & 30,75 & 33,200 & 0,737 & 61,94 & 10,38 \\
\hline & GK & 17,59 & 28,020 & 0,956 & 29,90 & 7,70 \\
\hline & $\mathbf{O K}+\mathbf{G K}$ & 48,34 & 31,315 & 0,817 & 91,84 & 18,08 \\
\hline & KK & 10,18 & 10,440 & 2,355 & 6,44 & 10,98 \\
\hline & $\mathbf{O K}+\mathbf{G K}+\mathbf{K K}$ & 58,52 & 27,68 & 1,08 & 98,28 & 29,06 \\
\hline & Jalovina & 41,48 & 0,683 & 3,734 & 1,72 & 70,94 \\
\hline & Ulaz & 100,00 & 16,485 & 2,18 & 100,00 & 100,00 \\
\hline
\end{tabular}

$\mathrm{Na}$ osnovu rezultata prikazanih u tabeli 2, može se konstatovati sledeće:

- Primenom postupka flotiranja datog na slici 2, dobijeni su najbolji rezul-tati kako u pogledu sadržaja $\mathrm{P}_{2} \mathrm{O}_{5}$, tako i u pogledu sadržaja minerala jalovine. Naime sadržaj $\mathrm{P}_{2} \mathrm{O}_{5} \quad \mathrm{u}$ osnovnom koncentratu (OK) opita 1 je 35,50\%, dok je u OK opita $233,20 \%$. U skupnom koncentratu $(\mathrm{OK}+\mathrm{GK})$ opita 1 sadržaj $\mathrm{P}_{2} \mathrm{O}_{5}$ je $32,407 \%$, a u opitu 2 je $31,315 \mathrm{P}_{2} \mathrm{O}_{5}$ ), pri tome je iskorišćenje $\mathrm{P}_{2} \mathrm{O}_{5}$ u skupnom koncentratu $\mathrm{u}$ oba opita preko $91,50 \%$.
- Sadržaj $\mathrm{Fe}_{2} \mathrm{O}_{3}$ u oba skupna koncentrata je nizak i u opitu $1 \mathrm{OK}+\mathrm{GK}$ je $0,801 \% \mathrm{Fe}_{2} \mathrm{O}_{3}$, a u opitu $2 \mathrm{OK}+\mathrm{GK}$ je $0,818 \% \mathrm{Fe}_{2} \mathrm{O}_{3}$.

- Što se tiče kontrolnih koncentrata KK njihov kvalitet je slabiji u pogledu sadržaja $\mathrm{P}_{2} \mathrm{O}_{5}$ nego u ulaznoj sirovini (KK u opitu 1 je 11,30\% $\mathrm{P}_{2} \mathrm{O}_{5}$, a u opitu 2 je 10,44\% $\mathrm{P}_{2} \mathrm{O}_{5}$ ). Iskorišćenje $\mathrm{P}_{2} \mathrm{O}_{5}$ u KK opita 1 je $7,10 \%$, dok je sadržaj $\mathrm{Fe}_{2} \mathrm{O}_{3}$ 2,283\%. Iskorišćenje $\mathrm{P}_{2} \mathrm{O}_{5}$ u KK opita 2 je 6,44 \%, dok je sadržaj $\mathrm{Fe}_{2} \mathrm{O}_{3} \quad 2,355 \%$. Na osnovu dobijenih rezultata uočava se da je 
sadržaj $\mathrm{Fe}_{2} \mathrm{O}_{3}$ u kontrolnim koncentratima oba opita veći od sadržaja $u$ ulaznoj sirovini koji iznosi 2,16\%.

- sadržaj $\mathrm{P}_{2} \mathrm{O}_{5}$ u jalovini je takođe veoma nizak, $0,525 \%$ u opitu 1 i 0,683 u opitu 2, tako da je na osnovu toga $\mathrm{i}$ gubitak $\mathrm{P}_{2} \mathrm{O}_{5} \mathrm{u}$ jalovini veoma nizak 1,33 i $1,72 \%$.

- kada se uporede ova dva opita vidi se da je postignut bolji kvalitet osnovnog koncentrata $\mathrm{u}$ opitu $135,50 \% \quad \mathrm{P}_{2} \mathrm{O}_{5}$ kada imamo kraće vreme kondicioniranja za fazu osnovnog flotiranja (10 min. u opitu $1 ; 20$ min. u opitu 2) u odnosu na opit 2 kada je kvalitet koncentrata $33,20 \% \quad \mathrm{P}_{2} \mathrm{O}_{5}$. Iz ovoga možemo izvući zaključak da produženo vreme kondicioniranja može dovesti do desorpcije oleata sa površine apatita i pošto je osnovni koncentrat opita 2 maseno veći od OK opita 1 za oko 1,7\%, da sa produženim vremenom kondicioniranja dolazi do aktiviranja površina minerala jalovine $\mathrm{i}$ njihovog flotiranja u koncentrat., Zbog toga je iskorišćenje $\mathrm{P}_{2} \mathrm{O}_{5}$ kod ova dva koncentrata skoro isto i iznosi $61,77 \%$ i $61,94 \%$ a kvalitet je različit.

$\mathrm{Na}$ osnovu izvedenenih laboratorijskih ispitivanja, i dobijenih rezultata (tabela 2) definisana je tehnološka šema poluindustrijskog procesa i prikazana je na slici 3 .

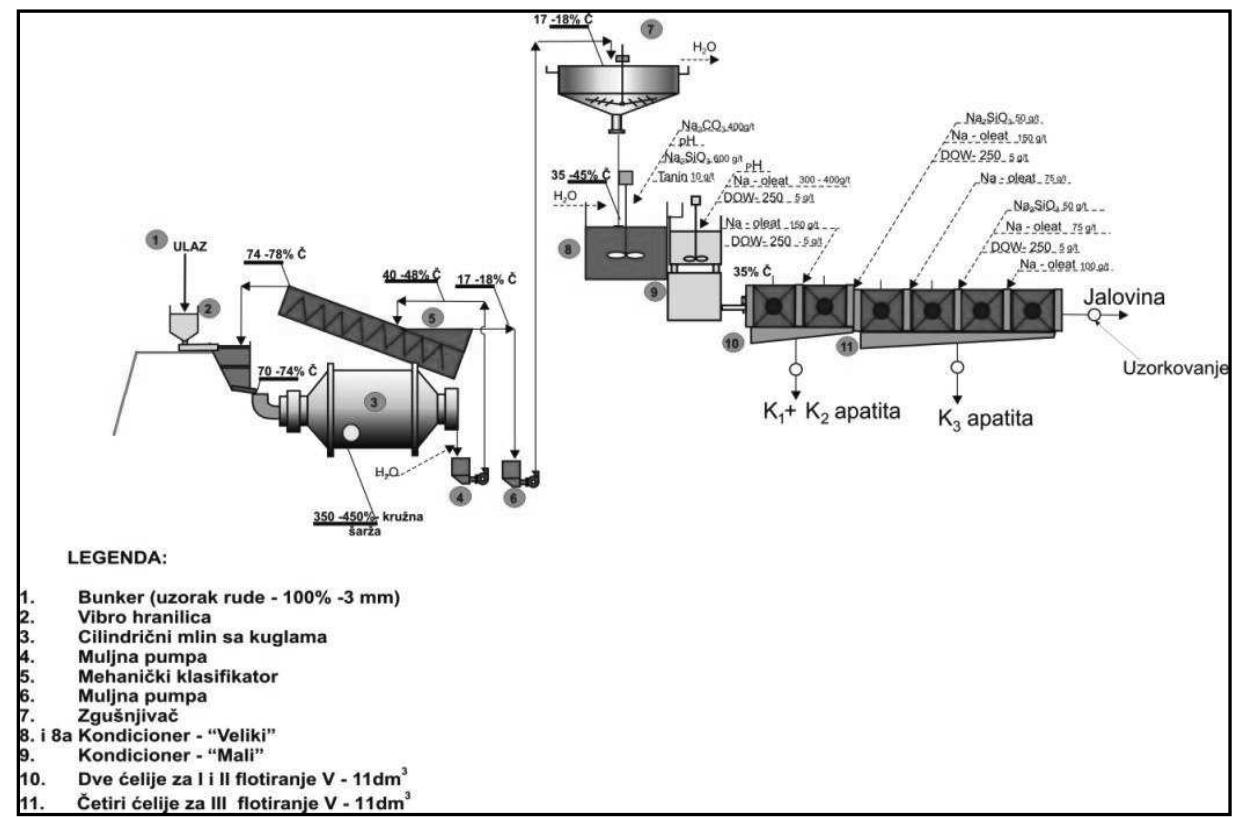

Sl. 3. Definisana tehnološka šema flotiranja apatita iz rude fosfata ,Lisina” $u$ poluindustrijskim uslovima rada

\section{ZAKLJUČAK}

Fosfati su strateška sirovina u svetskim okvirima neophodna za proizvodnju mineralnih đubriva a samim tim i hrane. Zbog dugotrajne eksploatacije bogata ležišta fosfata su iscrpljena, a iz ležišta sa nižim sadržajem $\mathrm{P}_{2} \mathrm{O}_{5}$ koncentrati se dobijaju 
postupkom flotiranja. Kako se minerali tipa soli (pre svih kalcit $\mathrm{CaCO}_{3}$ i magnezit $\mathrm{MgCO}_{3}$ ) veoma često nalaze $\mathrm{u}$ mineralnoj paragenezi sa apatitom to je postupak njegovog slektivnog flotiranja iz ovakvih ruda veoma komlikovan a nekada i nemoguć.

$\mathrm{Na}$ osnovu rezultata prikazanih $\mathrm{u}$ ovom radu može se zaključiti da su u opitima flotiranja dobijeni koncentrati dobrog kvaliteta. Naime, sadržaj $\mathrm{P}_{2} \mathrm{O}_{5} \mathrm{u}$ osnovnom koncentratu opita 1 je $35,50 \%$, a sardžaj $\mathrm{P}_{2} \mathrm{O}_{5}$ opita 2 je $33,20 \%$. Sadržaj $\mathrm{P}_{2} \mathrm{O}_{5}$ u skupnom koncentratu opita 1 je $32,407 \%$ dok je u opitu 2 31,315\%. Iskorišćenje $\mathrm{P}_{2} \mathrm{O}_{5} \mathrm{u}$ skupnim koncentratima oba opita je preko 91,5\%. Takodje u oba opita su uspešno deprimirani minerali gvoždja. Naime sadržaj $\mathrm{Fe}_{2} \mathrm{O}_{3}$ u oba skupna koncentrata je oko $0,8 \%$ što je daleko manje od 1,5\% koliko propisuje hemijska industrija. Nešto lošiji rezultati opita $2 \mathrm{u}$ pogledu kvaliteta koncentrata mogu se pripisati produženom vremenu kondicioniranja zbog koga dolazi do desorpcije kolektora sa površine apatita kao i aktiviranja površina minerala jalovine i njihovog flotiranja u koncentrat. Rezultati opita flotiranja su poslužili kao osnova za definisanje tehnološkog postupka flotiranja fosfata $u$ poluindustrijskim uslovima rada.

\section{LITERATURA}

[1] D. S. Radulović, D. Vučinić, M. Stojanović, B. Ivošević, D. Todorović, V. Jovanović, Z. Bartulović: "Unapredjenje tehnološkog postupka flotiranja apatita iz fosforitne rude „Lisina“, povećanjem sadržaja čvrste faze sa 25 na $35 \%$, u laboratorijskim i poluindustrijskim uslovima", Tehničkotehnološko rešenje M84, 2013.
[2] D. S. Radulović: "Uticaj jona apatita i kalcita na njihove površinske osobine", doktorska disertacija, Rudarsko-geološki fakultet, Univerzitet u Beogradu, 2011.

[3] S. Milošević, D. Radulović, B. Ivošević, V. Antanasković, D. Vidanović, V. Đošić, Studija izvodljivosti: "Eksploatacija fosforitne rude iz ležišta "Lisina" kod Bosilegrada i proizvodnja koncentrata fosfata $\left(\mathrm{K} / \mathrm{P}_{2} \mathrm{O}_{5}\right)$ tržišnog kvaliteta" Knjiga 2: "Primarna prerada fosforitne rude "Lisina" - proizvodnja koncentrata fosfata $\left(\mathrm{K} / \mathrm{P}_{2} \mathrm{O}_{5}\right)$ tržišnog kvaliteta", Tehnolološko-mašinski deo: Arhiva ITNMS-a, Beograd, 2008.

[4] J. Pavlica, D. Draškić: "Priprema nemetaličnih mineralnih sirovina", Rudarsko-geološki fakultet, Beograd, 1997.

[5] A. Z. M. Abouzeid, Int. J. Miner. Process. 85 (2008) 59-84.

[6] M. Prasad, A.K. Maajmudar, T.C. Rao, SME Min. Metall. Process. 17 (1), (2000), pp. 49-55.

[7] N. Ćalić: "Teorijski osnovi pripreme mineralnih sirovina", Beograd, 1990.

[8] H. Sis, S. Chander, Minerals Engineering 16 (2003), pp. 577-585.

[9] P. Somasundaran, B. Markovic, Interfacial properties of calcium phosphates. In: Amjad, Z. (Ed.), Calcium Phosphates in Biological and Industrial Systems. Kluwer Academic Publishers, Dordrecht, 1998, pp. 185-201.

[10] A. M. Gaudin,: "Flotation", McGraw Hill Book Co, 1957.

[11] Đ. Lešić, S. Marković: "Priprema mineralnih sirovina", Beograd, 1968.

[12] H. S. Hana, and P. Somasundaran, "Flotation of Salt-Type Minerals", in M. C. Fuerstenau (Ed.), Flotation, A. M. Gaudin Memorial Vol. 1, AIME, New York, NY, (1976), pp. 197-271. 
[13] R. P. King, (Ed): "Principles of Flotation", "Semisoluble salt flotation", M. C. Fuerstenau, Institute of Mining and Metallurgy, Johanesburg, 1982.

[14] S. Milošević: "Flotacijska koncentracija “, Beograd, 1994.
[15] M. Petrov, Lj. Andrić, Ž. Sekulić, V. Jovanović:Modelovanje rada mlina prema gustini šarže mlina i specifičnom kapacitetu, Mining and Metallurgy Engineering Bor, 1/2014, str. 129-136 